BMJ Open Sport \& Exercise Medicine

\title{
Risk factors associated with injury and concussion in sanctioned amateur and professional mixed martial arts bouts in Calgary, Alberta
}

\author{
Gwynn Curran-Sills, Tasnima Abedin
}

To cite: Curran-Sills G, Abedin T. Risk factors associated with injury and concussion in sanctioned amateur and professional mixed martial arts bouts in Calgary, Alberta. BMJ Open Sport \& Exercise Medicine 2018;4:e000348. doi:10.1136/ bmjsem-2018-000348

Accepted 30 May 2018

\section{Check for updates}

Family Medicine and Primary Care Research Office, University of Calgary, Calgary, Alberta, Canada

Correspondence to Dr Gwynn Curran-Sills; gwynn. curran.sills@utoronto.ca

\section{ABSTRACT}

Background There is limited literature that examines risk factors for injury and mild traumatic brain injury (mTBI) in mixed martial arts (MMA). An examination of previously unstudied bout and athlete characteristics that may pose health risks while partaking in this sport is warranted. Hypothesis/purpose To determine the incidence of injury and concussion, along with the identification of risk factors that contribute to injury and $\mathrm{mTBI}$ in amateur and professional MMA bouts in Calgary, Alberta.

Study design A retrospective cohort study with casecontrol design.

Methods Calgary amateur and professional MMA records were examined from 1 January 2010 to 31 December 2015. Descriptive statistics were used to describe the incidence of injury and concussion, along with univariate and multivariable logistic regression to identify risk factors for injury and $\mathrm{mTBI}$.

Results The injury rate per 100 athlete exposure (AE), the injury rate per $100 \mathrm{~min}$ of exposure and the concussion rate per $100 \mathrm{AE}$ were 23.6 (95\% $\mathrm{Cl} 20.5$ to 27.0 ), 4.1 (95\% Cl 3.48 to 4.70$)$ and 14.7 (95\% Cl 11.8 to 17.2$)$, respectively. The most common location of injury was the head and mTBI was the most common type of injury. Athletes whose bout was finished by a knockout/technical knockout, corner stoppage, draw, no contest or physician, and those whose country of origin was non-Canadian, were more likely to sustain an injury. No risk factors for concussion were shown to be significant.

Conclusion Engaging in MMA exposes athletes to inherent risk and several recommendations are proposed to reduce these risks. Future prospective investigations are necessary to better delineate the findings in this study.

\section{INTRODUCTION}

Combat sports are competitive contact sports where athletes use striking, grappling or weapon-related techniques under specific rules of engagement to simulate parts of real handto-hand combat. These sports have a long tradition in Canada and include: boxing, kickboxing, Muay Thai, wrestling, mixed martial arts (MMA) and other traditional forms of martial arts. Both in Canada and internationally, MMA has garnered considerable
What is known about the subject?

- There is limited literature concerning the incidence of injuries and head trauma in mixed martial arts (MMA) or the identification of associated risk factors.

What this study adds to existing knowledge?

- Athletes whose bouts were finished by a knockout/ technical knockout, corner stoppage, draw, no contest or physician and those whose country of origin was non-Canadian were more likely to sustain an injury.

- None of the variables examined as risk factors for mild traumatic brain injury were shown to be significant.

- Engaging in MMA exposes athletes to inherent risk and several recommendations are proposed to reduce these risks.

growth despite calls for banning the sport by medical associations in Australia, ${ }^{1}$ Canada, the $\mathrm{UK}^{3}$ and the USA. ${ }^{4}$ Since the inception of MMA in the 1990s, spectator viewership ${ }^{5}$ and revenues ${ }^{6}$ have continued to increase dramatically, highlighting the public's sustained interest and continued growth of the sports. As such, it behooves the medical community to engage in evidence-based investigation to understand the morbidity patterns that have evolved in the sport and propose interventions that can mitigate these patterns.

A handful of studies have examined risk factors associated with injury ${ }^{7-11}$ and head trauma $^{1112}$ in MMA. These studies have focused on athletes predominately competing within Nevada, USA, and events hosted predominately by a single MMA promotional organiser. The current literature has examined associations between injuries and potential risk factors such as age, sex, weight, match outcome and bout length. A meta-analysis of these studies $^{8}$ has revealed that contests in the heavyweight class, title fights, bouts that last longer, bouts that are 
decided by knockout (KO), technical knockout (TKO) or decision, and the loser of a bout resulted in higher rates of injuries. While risk factors associated with mild traumatic brain injury $(\mathrm{mTBI})^{13}$ included age $\geq 35$ years, competition in heavyweight class, shorter bout length, previous $\mathrm{KO} / \mathrm{TKO}$ and match significance. Developing a deeper analysis of the characteristics that may contribute to injuries in MMA is warranted as there are other variables that intuitively could contribute to injury patterns. Chief among these variables are matchmaker (these individuals within an MMA promotional organisation who determine which athletes will compete against one another), referee (these individuals are largely responsible for the athletes' safety during the contest), level of competition (amateur and professional levels), athlete experience and athlete's country of origin (this dictates the athlete's available training resources which can vary drastically by geographic region). The objectives for this study were to (1) determine the incidence of injury and concussion and (2) identify risk factors that contribute to injury and mTBI in amateur and professional MMA bouts in Calgary.

\section{METHODS}

\section{Study population}

A retrospective cohort study examined amateur and professional MMA bouts that occurred in Calgary from 1 January 2010 to 31 December 2015. The data for the study were derived from the Calgary Combative Sports Commission (CCSC) official records, which included athlete demographic information, level of competition, outcome of the contest, bout length, suspension length, injuries, names of commission officials including referee and the matchmaker. A mixture of regional and international MMA promotional organisations were included in the dataset. The athlete's amateur and/or professional records were determined from www.mixedmartialarts. com/fighter, ${ }^{14}$ the official record keeper for MMA results in partnership with the Association of Boxing Commission $(\mathrm{ABC})$. Amateur and professional rounds lasted three and five minutes, respectively. Non-title and title bouts were three and five rounds, respectively. Amateur rules for MMA in Calgary did not allow for strikes to the head of a grounded opponent.

During an MMA event, at least one ringside physician and two nurses, along with paramedic coverage, were present. Post-bout, each athlete was assessed by a physician to identify injuries, determine if any further investigation(s) was required and establish the length of suspension (which ranged from a minimum of 14 days to indefinite). From January 2010 to December 2015, there were 15 unique ringside physicians who examined athletes.

\section{Study definitions}

Athlete exposure (AE) was defined as one athlete being exposed to the potential of incurring injury during a single bout. One minute of exposure (ME) was defined as one athlete partaking in one minute of a bout, that is, during a bout with two athletes each minute of the bout would represent two ME. No specific definition was established for the reporting of injuries by these physicians during the post-bout medical examination. For the purposes of this study, injury was defined as an entry on the CCSC post-bout medical examination record. These were categorised broadly as concussion, fracture, laceration and injury (any soft tissue injury or unspecified injury). mTBI or concussion (a subset of $\mathrm{mTBI}^{15}$ ) was defined as the occurrence of a $\mathrm{KO}$ or TKO recorded on the CCSC post-bout medical examinationl. A KO clearly meets the current criteria for a concussion, ${ }^{16}$ while a TKO is not as clear. TKO is defined under the Unified Rules of MMA as the termination of a bout due to a severe injury that resulted from a legal maneuver and others ${ }^{12}{ }^{13}$ have argued that a significant proportion of TKOs meet the criteria for concussion. ${ }^{16}$ For this study, all TKOs were assumed to have led to a concussion despite the mechanism of injury (please see the Limitation section for further discussion of this definition). Concussion rate was defined as the number of KOs and TKOs.

\section{Statistical analysis}

Descriptive statistics were used to determine the incidence of injury and concussion; frequencies (percentages) were presented for categorical data, and mean (SD) presented for continuous data. The rate of injury was normalised to $100 \mathrm{AE}$ and $100 \mathrm{ME}$, while the concussion rate was normalised to $100 \mathrm{AE}$. A case-control design with univariate and multivariable logistic regressions were used to determine if variables associated with the bout (ie, level of competition, bout type, length of the bout, outcome of the bout, matchmaker, promotional organisation, referee) and athlete (ie, age, sex, weight, athlete experience, country of origin) affected the incidence of injury or concussion. A case was defined as an athlete who sustained an injury during competition, while a control was defined as an athlete who was not injured during competition. Bouts in which both athletes were not injured or both athletes were injured were excluded. Two regression models were used to (1) confirm that previously identified risk factors of injury and mTBI in MMA were statistically significant in this dataset and to (2) examine if matchmaker (since one MMA promotional organisation was dominant in terms of its number of events in the CCSC dataset, the matchmaker for this organisation was compared with all other matchmakers), referee ( $<50$ and $\geq 50$ bouts refereed), level of competition (amateur vs professional), athlete's prior experience (sum of amateur and professional fights) and athlete's country of origin (Canadian vs non-Canadian) contributed as risk factors to injury and concussion. The difference between injured and non-injured athletes was determined with two-sample t-test for continuous variables and $\chi^{2}$ for categorical variables. P-values $<0.05$ were a priori considered statistically significant and $95 \%$ CIs were reported. SPSS 22 software was used to conduct the statistical analyses. 
Table 1 Calgary MMA data characteristics from January 2010 to December 2015

\begin{tabular}{|c|c|c|c|c|c|c|c|c|}
\hline \multirow[b]{2}{*}{ Year } & \multirow{2}{*}{$\begin{array}{l}\text { Total no of } \\
\text { events }\end{array}$} & \multirow{2}{*}{$\begin{array}{l}\text { No of events } \\
\text { analysed, } n(\%)\end{array}$} & \multirow{2}{*}{$\begin{array}{l}\text { No of } \\
\text { athletes }\end{array}$} & \multirow{2}{*}{$\begin{array}{l}\text { No of injured } \\
\text { athletes, } n(\%)\end{array}$} & \multirow[b]{2}{*}{ No of injuries } & \multicolumn{3}{|c|}{ Injured athlete outcome } \\
\hline & & & & & & Winner & Loser & Draw/NC \\
\hline 2010 & 5 & $4(80.0)$ & 72 & $13(18.1)$ & 15 & 1 & 12 & 0 \\
\hline 2011 & 8 & $7(87.5)$ & 136 & $26(19.1)$ & 26 & 1 & 25 & 0 \\
\hline 2012 & 10 & $7(70.0)$ & 144 & $38(26.4)$ & 41 & 8 & 30 & 0 \\
\hline 2013 & 4 & $3(75.0)$ & 66 & $15(22.7)$ & 15 & 1 & 13 & 1 \\
\hline 2014 & 6 & $6(100)$ & 116 & $22(19.0)$ & 24 & 3 & 19 & 0 \\
\hline 2015 & 8 & $8(100)$ & 152 & 37 (24.3) & 41 & 5 & 31 & 1 \\
\hline Total & 41 & $35(85.4)$ & 686 & $151(22.0)$ & 162 & 19 & 130 & 2 \\
\hline
\end{tabular}

MMA, mixed martial arts; NC, no consent.

MMA, mixedmartial arts; NC, no consent.

\section{RESULTS}

\section{Event and athlete characteristics}

During the study period, there were 41 MMA events held in Calgary. Thirty-five $(85.4 \%)$ of these events were included for analysis, which generated 343 bouts (table 1 ) with $51.0 \%$ being at the professional level. No CCSC records could be obtained for the other six events. Of the six MMA promotional organisations that hosted events in Calgary, one organisation was responsible for $83.1 \%$ of events. This organisation's matchmaker accounted for $69.8 \%$ of bouts and the other five matchmakers represented $31.2 \%$. Bouts were officiated by 15 referees, 11 and 4 with $>50$ and $\geq 50$ bouts of experience, respectively. These four referees officiated $69.1 \%$ of all bouts. The average number of bouts officiated by a referee in Calgary was $22.9( \pm 24.4$, range 2-69) with a bimodal distribution that centred around 6 and 59. Males competed in $96.8 \%$ of matches, and non-title matches accounted for $89.7 \%$ of matches.

The characteristics of injured and non-injured athletes are presented in table 2 . The average suspension length for an injured athlete was 39.1 days ( \pm 26.3 , range $14-180$ ) and 15.5 days $( \pm 6.2$, range $7-60)$ for non-injured athletes.

\section{Incidence of injury and concussion}

There were 151 athletes who sustained an injury, giving a total of 162 injuries (table 1). The number of AEs was 686 . The total number of scheduled minutes was 4280 and $75.4 \%$ of bouts ended early, resulting in 2000 minutes of bout time or 4000 minutes of exposure. The injury rate per $100 \mathrm{AE}$, the injury rate per $100 \mathrm{ME}$ and the concussion rate per $100 \mathrm{AE}$ were 23.6 (95\% CI 20.5 to 27.0), 4.1 (95\% CI 3.48 to 4.70$)$ and 14.7 (95\% CI 11.8 to $17.2)$, respectively. The most common injury location was the head, followed by the upper and lower extremities (table 3). Concussion was the most common injury type.

\section{Risk factors for injury and mTBI}

Athletes whose bout was finished by a $\mathrm{KO} / \mathrm{TKO}$ and by other (corner stoppage, draw, no contest or physician stoppage) were 10.08 (95\% CI 5.99 to 16.96 ) and 3.76 (95\% CI 1.28 to 11.40 ) times more likely to sustain an injury, respectively, when controlled for age, sex, weight, bout length and bout type (table 4). Athletes whose country of origin was non-Canadian were 2.30 (95\% CI 1.34 to 3.93 ) times more likely to sustain an injury when controlled for referee, prior experience, level of competition and matchmaker. None of the variables examined as risk factors for mTBI were shown to be statistically significant in the multivariable regression model (table 5).

\section{DISCUSSION}

The injury rate per $100 \mathrm{AE}$ was 23.6 (95\% CI 20.5 to 27.0) for the Calgary dataset and is in keeping with the rate reported in a recent systematic review ${ }^{8}$ of 22.9 (95\% CI 11.0 to 47.4). The injury rate per $100 \mathrm{AE}$ for other combative sports is reported as 11.9-25.1 in professional boxing, ${ }^{17}{ }^{18-20} 7.9$ in taekwondo, ${ }^{21} 7.8$ in amateur boxing $^{22}$ and 4.4 in judo. ${ }^{23}$ These rates only serve as a guide, as comparing MMA with other types of combative sports is difficult given the considerable methodological difference between each of these studies, of which the operational definition for an injury can be quite varied. Even if a reliable comparison was possible, it would be difficult to tease out the specific reasons for any observed differences. This is especially true given that these sports are being contested under different rules, some only allow specific types or parts of the body to be struck, others do not allow striking at all and in some protective equipment is worn. Frequencies of lacerations and soft tissue injuries $(32.1 \%)$ and fractures $(5.6 \%)$ are in keeping with the literature, ${ }^{8}$ although these are on the lower end of the incidence of these injuries.

The concussion rate per $100 \mathrm{AE}$ was 14.7 (95\% CI 11.8 to 17.2) for this study and this rate has previously been reported as $28.3^{12}$ and $15.9^{13}$ per 100 AE for MMA. An alternative means to represent concussion risk would be in the context of an athlete's career. For the Calgary dataset, the concussion rate can also be reported as 0.294 concussions/contest. A similar rate can be derived for professional American football ${ }^{24}$ (0.4114 concussions/ contest), Canadian junior ice hockey ${ }^{25}$ (0.4038 concussions/contest) and English professional Rugby union ${ }^{26}$ (0.1119 concussion/contest). One can estimate the number of concussions for one athlete over a 10-year 
Table 2 Injured and non-injured athlete characteristics for Calgary MMA matches from January 2010 to December 2015

\begin{tabular}{|c|c|c|}
\hline Characteristic & Injured $(n=151)$ & Non-injured $(n=535)$ \\
\hline Sex, $\mathrm{n}$ (\% of males) & $147(97.4)$ & $515(96.4)$ \\
\hline Average age (years)* & $26.9( \pm 5.5,16-44)$ & $26.6( \pm 5.4,14-46)$ \\
\hline Average weight (pounds) ${ }^{\star}$ & $169.5( \pm 25.6,115.5-265.5)$ & $163.5( \pm 25.0,105.5-268.0)$ \\
\hline Average experience (no of bouts) ${ }^{\star}$ & $6.2( \pm 7.7,0-36)$ & $5.1( \pm 6.6,0-60)$ \\
\hline Level of competition, $\mathrm{n}$ ( $\%$ of professional) & $88(58.3)$ & $272(50.9)$ \\
\hline Non-title fight, n (\%) & $131(86.8)$ & $484(90.5)$ \\
\hline \multicolumn{3}{|l|}{ Country of origin, n (\%) } \\
\hline Canadian & $121(80.1)$ & $485(90.6)$ \\
\hline Non-Canadian & $24(15.9)$ & $32(6.0)$ \\
\hline Unknown & $6(4.0)$ & $18(3.4)$ \\
\hline Dominant matchmakers, n (\%) & $102(67.5)$ & $379(70.8)$ \\
\hline Referees $\geq 50$ bouts experience, $n(\%)$ & $106(70.2)$ & $381(71.2)$ \\
\hline Average time bout finished (mins) ${ }^{*}$ & $5.3( \pm 4.8,0.1-25.0)$ & $6( \pm 4.9,0.1-25.0)$ \\
\hline Percentage of bout completed & 39.7 & 48.8 \\
\hline Loser of the bout, $\mathrm{n}(\%)$ & $130(86.1)$ & $207(38.7)$ \\
\hline \multicolumn{3}{|l|}{ How bout was finished, n (\%) } \\
\hline $\mathrm{KO}$ & $21(13.9)$ & $20(3.8)$ \\
\hline TKO & $77(51.0)$ & 85 (15.9) \\
\hline Submission & $23(15.2)$ & $265(49.5)$ \\
\hline Decision & $22(14.6)$ & $147(27.5)$ \\
\hline Physician stoppage & $4(2.6)$ & $5(0.9)$ \\
\hline Other† & $4(2.6)$ & $13(2.4)$ \\
\hline No of indefinite suspensions & 43 & 4 \\
\hline Average suspension length (days) & $39.1( \pm 26.3,14-180)$ & $15.5( \pm 6.2,7-60)$ \\
\hline
\end{tabular}

${ }^{*}$ All averages include the SD and range in parentheses.

†Corner stoppage, draw, no contest.

$\mathrm{KO}$, knockout; MMA, mixed martial arts; TKO, technical knockout.

career if the following assumptions are made: the athletes play at a professional level, the total number of athletes for a team is the number of positions of play on the team ${ }^{\text {ii }}$ and there are no missed games due to injury or other circumstances. With these assumptions, this would equate to the following number of career concussion over a 10 year: ice hockey (27.6), MMA (4.4), American football (2.2) and Rugby union (0.8). When viewed in the context of career risk, it appears that MMA does not confer the same exposure to concussion as seen in other popular sports. However, this simplified derivation

\footnotetext{
${ }^{\mathrm{i}}$ The number of concussion expected for one athlete over a 10 -year career $=[($ concussion $/$ contest $) *($ no of contest $/$ season $) *(10$ years $)] /$ $[(2$ teams $) *($ no of positions on the team $)]$. As an example, for ice hockey this is $(0.4038) *(82) *(10) / 2 *(6)$. For ice hockey, professional American football, MMA and English profession Rugby union, the number of professional games/season are 82, 16, 3 and 22, respectively. ${ }^{\text {ii }}$ For ice hockey, professional American football, MMA and English professional Rugby union, the number of positions of play on a team are $6,15,1$ and 15, respectively. This number was used since an athlete must be competing to sustain a concussion and this number best describes the number of athletes at risk during a game.
}

should be viewed with caution given the assumptions that were made, since the baseline concussion per contest rates come from a diverse set of methodologically different studies, and within each of these sports there is no recognised baseline concussion rate in the literature.

Non-Canadian athletes are at a significant risk of acquiring an injury when competing in MMA contests in Calgary. It is possible that uneven matchmaking may contribute to this finding. The $\mathrm{ABC}$ is predominately subscribed to by American and Canadian commissions. Athletes who have competed in these jurisdictions will have the results of an event forwarded to the $A B C$ to register suspensions and contest outcomes. For American and Canadian athletes and commissions, it is possible for an objective matchmaking process to occur. However, for athletes who are competing outside of these countries, there may not be the same pressure for commissions to provide this information to the $\mathrm{ABC}$ or other centralised organisation. As such, when matchmaking occurs for non-Canadian athletes in Canada it may not be an informed process if there is no information availble through the ABC. 
Table 3 Summary of injury location and type categorised by how the matched ended for Calgary MMA competition: January 2010 to December 2015

\begin{tabular}{|c|c|c|c|c|c|c|c|c|}
\hline & \multirow{2}{*}{$\begin{array}{l}\text { Frequency } \\
\text { (\%) of injury } \\
\text { location/type† }\end{array}$} & \multicolumn{7}{|c|}{ Frequency of matches ended by:* } \\
\hline & & KO & TKO & $\begin{array}{l}\text { Submission- } \\
\text { choke }\end{array}$ & $\begin{array}{l}\text { Submission- } \\
\text { joint manipulation }\end{array}$ & $\begin{array}{l}\text { Physician } \\
\text { stoppage }\end{array}$ & Decision¥ & Other§ \\
\hline \multicolumn{9}{|l|}{ Injury location } \\
\hline Head & 116 (71.6) & 21 & 78 & 4 & 0 & 3 & 9 & 1 \\
\hline Ocular & $7(4.3)$ & 1 & 1 & 0 & 0 & 1 & 4 & 0 \\
\hline $\begin{array}{l}\text { Upper } \\
\text { extremity }\end{array}$ & $18(11.1)$ & 0 & 2 & 3 & 7 & 0 & 6 & 0 \\
\hline $\begin{array}{l}\text { Lower } \\
\text { extremity }\end{array}$ & $14(8.6)$ & 0 & 1 & 2 & 6 & 1 & 4 & 0 \\
\hline Otherף & $7(4.3)$ & 0 & 1 & 2 & 0 & 0 & 3 & 1 \\
\hline Total & $162(100.0)$ & $22(13.6)$ & $83(51.2)$ & $11(6.8)$ & $13(8.0)$ & $5(3.1)$ & $26(16.0)$ & $2(1.2)$ \\
\hline \multicolumn{9}{|l|}{ Injury type } \\
\hline Concussion ${ }^{\star *}$ & $101(62.3)$ & 21 & 73 & 3 & 0 & 2 & 2 & 0 \\
\hline Fractures & $9(5.6)$ & 0 & 2 & 1 & 1 & 1 & 4 & 0 \\
\hline Injury†† & $46(28.4)$ & 1 & 7 & 6 & 12 & 2 & 16 & 2 \\
\hline Lacerations & $6(3.7)$ & 0 & 1 & 1 & 0 & 0 & 4 & 0 \\
\hline Total & $162(100.0)$ & $22(13.6)$ & 83 (51.2) & $11(6.8)$ & $13(8.0)$ & $5(3.1)$ & 26 (16.0) & $2(1.2)$ \\
\hline
\end{tabular}

*Percentages are included in parentheses.

†There were 151 athletes and 162 injuries.

‡Defined as majority, split and unanimous decisions.

$\S$ Defined as corner stoppage, no contest and draw.

ๆDefined as dental, torso and groin injuries and unspecified lacerations.

${ }^{*}$ Used KO/TKO as a surrogate for concussion.

††Defined as soft tissue injuries and unspecified injuries.

$\mathrm{KO}$, knockout; mTBI, mild traumatic brain injury; MMA, mixed martial arts; TKO, technical knockout.

Intuitively, matchmaker and referee were expected to influence the risk for injury and mTBI in MMA athletes. Each of these individuals plays a pivotal role, one creating contests where appropriately matched athletes compete against one another and the other ensuring a fair contest, while trying to minimise the health risks of the athletes. In the context of the CCSC data, neither matchmaker nor referee was observed as a risk factor. In part, this may be related to the CCSC overseeing the matchmaking process to ensure an evenly matched contest and requiring each referee to undertake training to obtain a minimal skill set. However, it is suggested that future studies keep these risk factors in mind when conducting their analysis since this dataset may have been biased because there was only a single dominant matchmaker and a handful of dominant experienced referees.

A recent study $^{27}$ reported on the pre-bout medical screening of MMA athletes and identified $5.8 \%$ of athletes with medical reasons for termination of their bout. In this cohort, the most common reason for the match cancellation was abnormal neuroimaging, including post-traumatic gliosis, mircohaemorrhage, chronic orbital fractures and lacunar infarct. Ensuring standardised precontest medical screening prevents unsuitable athletes from participating in competition, exacerbating an existing health concern or creating a new health issue. Curran-Sills ${ }^{27}$ outlined several recommendations that included: the creation of guidelines regarding pre-bout and post-bout neuroimaging, the implementation of industry-wide minimum medical screening standards, the adoption of a longitudinal approach for weight monitoring and the development of competent ringside physician groups. Within the MMA community, there appears to be interest and will to implement some of these approaches to optimise MMA athlete health and reduce the risk of poor outcomes. Beyond these recommendations, it would be appropriate to consider more robust interventions to protect athletes engaged in amateur MMA. While others ${ }^{13}$ have recommended a ban on amateur MMA, it does not seem realistic to believe that this will be accomplished when there are many popular sports with inherent health risks that the public continue to engage in. Perhaps alternative inventions could include: restriction of those who have previously competed in an unsanctioned event from competing in a sanctioned event; the use of protective head equipment as worn in Olympic taekwondo and previously worn in Olympic boxing; limiting the types of techniques that amateur athletes are exposed too in competition; a modified form of the standing 8-count that is commonly used in boxing after a knock down; or educational programmes aimed at publicizing appropriate return-to-play guides as 
Table 4 Risk factors for injury in Calgary MMA athletes from January 2010 to December 2015

\begin{tabular}{|c|c|c|c|c|}
\hline Variables & Unadjusted OR (95\% Cl) & $P$ value & Adjusted OR $(95 \% \mathrm{Cl})^{*}$ & $P$ value \\
\hline \multicolumn{5}{|l|}{ Set 1} \\
\hline Age (years) & 1.01 (0.98 to 1.05$)$ & 0.45 & 1.01 (0.97 to 1.05$)$ & 0.60 \\
\hline \multicolumn{5}{|l|}{ Sex } \\
\hline Female & Reference & - & Reference & - \\
\hline Male & 1.28 (0.43 to 3.84$)$ & 0.66 & 0.86 (0.24 to 3.06$)$ & 0.82 \\
\hline Weight (pounds) & 1.01 (1.00 to 1.02$)$ & 0.01 & 1.00 (1.00 to 1.01$)$ & 0.35 \\
\hline Bout length (seconds) & 0.999 (0.999 to 1.00$)$ & 0.10 & 1.001 (1.000 to 1.002$)$ & 0.29 \\
\hline \multicolumn{5}{|l|}{ How bout finished } \\
\hline Submission & Reference & - & Reference & - \\
\hline $\mathrm{KO} / \mathrm{TKO}$ & 10.65 (6.42 to 17.68$)$ & $<0.01$ & 10.08 (5.99 to 16.96$)$ & $<0.01$ \\
\hline Decision & 1.80 (0.98 to 3.35$)$ & 0.06 & 1.36 (0.62 to 2.99$)$ & 0.45 \\
\hline Other† & 4.74 (1.78 to 12.61$)$ & $<0.01$ & $3.76(1.28$ to 11.40$)$ & $<0.01$ \\
\hline \multicolumn{5}{|l|}{ Bout type } \\
\hline Non-title & Reference & - & Reference & - \\
\hline Title & 1.68 (0.89 to 3.19$)$ & 0.11 & 1.18 (0.84 to 3.80$)$ & 0.13 \\
\hline
\end{tabular}

Set 2

\begin{tabular}{|c|c|c|c|c|}
\hline \multicolumn{5}{|l|}{ Referee } \\
\hline$<50$ bouts experience & Reference & - & Reference & - \\
\hline$\geq 50$ bouts experience & $0.92(0.62$ to 1.36$)$ & 0.67 & $0.98(0.60$ to 1.60$)$ & 0.04 \\
\hline \multicolumn{5}{|l|}{ Country of origin } \\
\hline Canada & Reference & - & Reference & - \\
\hline Non-Canadian & 2.46 (1.50 to 4.04$)$ & $<0.01$ & 2.30 (1.34 to 3.93$)$ & $<0.01$ \\
\hline Prior experience (number) & 1.02 (1.00 to 1.05$)$ & 0.06 & 1.00 (0.97 to 1.03$)$ & 0.94 \\
\hline \multicolumn{5}{|l|}{ Level of competition } \\
\hline Amateur & Reference & - & Reference & - \\
\hline Professional & 1.46 (1.01 to 2.10$)$ & 0.04 & 1.37 (0.87 to 2.14$)$ & 0.18 \\
\hline \multicolumn{5}{|l|}{ Matchmaker } \\
\hline Others & Reference & - & Reference & - \\
\hline Dominant matchmaker & $0.83(0.57$ to 1.22$)$ & 0.35 & $0.86(0.54$ to 1.38$)$ & 0.54 \\
\hline
\end{tabular}

*Multivarible logistic regression of injured to non-injured after controlling for other variables in the set. †Other included corner stoppage, draw, no context, and physician stoppage.

$\mathrm{KO}$, knockout; MMA, mixed martial arts; TKO, technical knockout.

are actively pursued in other sports. Ultimately, it appears inappropriate to expose those engaged in amateur MMA to the same risks as would be experienced by a professional MMA athlete.

\section{LIMITATION}

A portion of the CCSC data $(14.6 \%)$ was unavailable for analysis and it is not clear what effect this would contribute to the results of this analysis. No specific definition was established for the reporting of injuries by physicians working with the CCSC during the post-bout medical examination. It is clear from the injury type data that under-reporting of soft tissue injuries was highly likely. Blinded data abstraction from the CCSC documentation was not undertaken. However, no interpretation of the data was required as the information in the documents was only translated into a database.

An arbitrary experience level of 50 CCSC sanctioned bouts was chosen to delineate experienced referees. It should be noted that referee experience did not consider that a referee may officiate in other jurisdictions or for other combative sports. As such, the approach taken in this study was a crude representation of a referee's experience level.

The definition of mTBI chosen by the investigator (ie, using $\mathrm{KO}$ and TKO as surrogates) does try to capture the frequency of concussion in MMA athletes, but it is likely this led to an overestimate of the incidence of mTBI as TKO can be due to a mechanism of injury other than head trauma. Future studies may consider implementing 
Table 5 Risk factors for mild traumatic brain injury in Calgary MMA athletes from January 2010 to December 2015

\begin{tabular}{|c|c|c|c|c|}
\hline Variables & Unadjusted OR $(95 \% \mathrm{Cl})$ & $P$ value & Adjusted OR $(95 \% \mathrm{Cl})^{*}$ & $P$ value \\
\hline \multicolumn{5}{|l|}{ Set 1} \\
\hline Age (years) & 0.99 (0.95 to 1.04$)$ & 0.776 & $0.99(0.95$ to 1.04$)$ & 0.792 \\
\hline \multicolumn{5}{|l|}{ Sex } \\
\hline Female & Reference & - & Reference & - \\
\hline Male & 1.49 (0.34 to 6.48$)$ & 0.597 & 0.88 (0.18 to 4.28$)$ & 0.87 \\
\hline Weight (pounds) & 1.01 (1.00 to 1.02$)$ & 0.01 & 1.01 (1.00 to 1.02$)$ & 0.063 \\
\hline Bout length (seconds) & 0.997 (0.996 to 0.998$)$ & $<0.01$ & 0.997 (0.996 to 0.998) & $<0.01$ \\
\hline \multicolumn{5}{|l|}{ Bout type } \\
\hline Non-title & Reference & - & Reference & - \\
\hline Title & 1.40 (0.63 to 3.10$)$ & 0.407 & $2.00(0.90$ to 4.65$)$ & 0.108 \\
\hline \multicolumn{5}{|l|}{ Set 2} \\
\hline \multicolumn{5}{|l|}{ Referee } \\
\hline$<50$ bouts experience & Reference & - & Reference & - \\
\hline$\geq 50$ bouts experience & 1.08 (0.66 to 1.75$)$ & 0.766 & 1.01 (0.56 to 1.83$)$ & 0.964 \\
\hline \multicolumn{5}{|l|}{ Country of origin } \\
\hline Canada & Reference & - & Reference & - \\
\hline Non-Canadian & 1.55 (0.83 to 2.90$)$ & 0.17 & $1.60(0.82$ to 3.13$)$ & 0.172 \\
\hline Prior experience (number) & $1.00(0.97$ to 1.04$)$ & 0.884 & 0.98 (0.94 to 1.02$)$ & 0.288 \\
\hline \multicolumn{5}{|l|}{ Level of competition } \\
\hline Amateur & Reference & - & Reference & - \\
\hline Professional & 1.38 (0.88 to 2.17$)$ & 0.165 & 1.53 (0.88 to 2.65$)$ & 0.128 \\
\hline \multicolumn{5}{|l|}{ Matchmaker } \\
\hline Others & Reference & - & Reference & - \\
\hline Dominant matchmaker & 0.81 (0.50 to 1.30$)$ & 0.374 & $0.84(0.48$ to 1.47$)$ & 0.538 \\
\hline
\end{tabular}

*Multivarible logistic regression of injured to non-injured after controlling for other variables in the set.

MMA, mixed martial arts.

precompetition and postcompetition concussion screening with the Sideline Concussion Assessment Tool or the Immediate Post-Concussion Assessment and Cognitive Testing to create more robust estimates of mTBI incidence. As there was no follow-up of athletes' clinical course or the ability to access possible neuroimaging for an athlete, it is not possible to conclude what severity of TBI they suffered from.

\section{CONCLUSION}

MMA continues to be a sport that requires investigation to generate evidence-informed understanding of the health risks and to create recommendations to modify these risks. Athletes whose bout were finished by a $\mathrm{KO} /$ TKO, corner stoppage, draw, no contest or physician and those whose country of origin was non-Canadian were more likely to sustain an injury. The most common location of injury was the head and concussion was the most common injury. None of the variables examined as risk factors for mTBI were shown to be significant. Engaging in MMA exposes athletes to inherent risk and several recommendations are proposed to reduce these risks.
Contributors This project was completed solely by TA and myself.

Funding The authors have not declared a specific grant for this research from any funding agency in the public, commercial or not-for-profit sectors.

Competing interests None declared.

Patient consent Not required.

Ethics approval University of Calgary Ethics Review Board (REB13-0837). .

Provenance and peer review Not commissioned; externally peer reviewed.

Open access This is an Open Access article distributed in accordance with the Creative Commons Attribution Non Commercial (CC BY-NC 4.0) license, which permits others to distribute, remix, adapt, build upon this work non-commercially, and license their derivative works on different terms, provided the original work is properly cited and the use is non-commercial. See: http://creativecommons.org/ licenses/by-nc/4.0/

(c) Article author(s) (or their employer(s) unless otherwise stated in the text of the article) 2018. All rights reserved. No commercial use is permitted unless otherwise expressly granted.

\section{REFERENCES}

1. Australian Medical Association. Mixed martial arts must be banned. http://www.amawa.com.au/mixed-martial-arts-mustbe- bannedama-wa/ (accessed 25 May 2017).

2. Canadian Medical Association. Mixed martial arts (MMA) ban. http:// www.cma.ca/advocacy/infocapsule-mma (accessed 25 May 2017). 
3. White $C$, White $C$. Mixed martial arts and boxing should be banned, says BMA. BMJ 2007;335:469.1-469.

4. American Medical Association. H-470.965 ultimate and extreme fighting. https://ssl3.ama-assn.org/apps/ecomm/Policy

FinderForm.pl?site=www.ama-assn.org\&uri=\%2fresources $\%$ 2fdoc \%2fPolicyFinder\%2fpolicyfiles\%2fHnE\%2fH-470.965. HTM(accessed 25 May 2017).

5. MMA Payout. The business of MMA. http://mmapayout.com/2010/ 11/the-ufc-fan-base/?utm_source=feedburner\&utm medium=feed\& utm_campaign=Feed\%3A+Payout+\%28Payout\%29\&utm_content= Google+Reader (accessed 25 May 2017).

6. Forbes. UFC sale officially closes for 4-billion. http://www.forbes. com/sites/noahkirsch/2016/08/22/ufc-sale-officially-closes-for4-billion-fertitta-brothers-earn-huge-payday/\#5952a2923c58 (accessed 25 May 2017).

7. Bledsoe GH, Hsu EB, Grabowski JG, et al. Incidence of injury in professional mixed martial arts competitions. J Sports Sci Med 2006;5(Cssi)CSSI):136-42.

8. Lystad RP, Gregory K, Wilson J. The epidemiology of injuries in mixed martial arts: a systematic review and meta-analysis. Orthop $\mathrm{J}$ Sports Med 2014;2:1.

9. McClain R, Wassermen J, Mayfield C, et al. Injury profile of mixed martial arts competitors. Clin J Sport Med 2014;24:497-501.

10. Ngai KM, Levy F, Hsu EB. Injury trends in sanctioned mixed martial arts competition: a 5-year review from 2002 to 2007. Br J Sports Med 2008;42:686-9.

11. Scoggin JF, Brusovanik G, Pi M, et al. Assessment of injuries sustained in mixed martial arts competition. Am J Orthop 2010;39:247-51.

12. Buse GJ. No holds barred sport fighting: a 10 year review of mixed martial arts competition. Br J Sports Med 2006;40:169-72.

13. Hutchison MG, Lawrence DW, Cusimano MD, et al. Head trauma in mixed martial arts. Am J Sports Med 2014;42:1352-8.

14. Mixed Martial Arts Inc. The official MMA fighter database. www. mixedmartialarts.com/fighter (accessed 25 May 2017).

15. Harmon KG, Drezner JA, Gammons M, et al. American Medical Society for Sports Medicine position statement: concussion in sport. Br J Sports Med 2013;47:15-26.
16. McCrory P, Meeuwisse WH, Aubry M, et al. Consensus statement on concussion in sport: the 4th International Conference on Concussion in Sport held in Zurich, November 2012. Br J Sports Med 2013;47:250-8.

17. Bledsoe GH, Li G, Levy F. Injury risk in professional boxing. South Med J 2005;98:994-8.

18. Zazryn T, Cameron P, McCrory P. A prospective cohort study of injury in amateur and professional boxing. $\mathrm{Br} J$ Sports Med 2006;40:670-4.

19. Zazryn TR, Finch CF, McCrory P. A 16 year study of injuries to professional boxers in the state of Victoria, Australia. Br J Sports Med 2003;37:321-4.

20. Zazryn TR, McCrory PR, Cameron PA. Injury rates and risk factors in competitive professional boxing. Clin J Sport Med 2009;19:20-5.

21. Lystad RP, Pollard H, Graham PL. Epidemiology of injuries in competition taekwondo: a meta-analysis of observational studies. $J$ Sci Med Sport 2009;12:614-21.

22. Estwanik JJ, Boitano M, Ari N. Amateur boxing injuries at the 1981 and 1982 USA/ABF National Championships. Phys Sportsmed 1984;12:123-8

23. Frey $A$, Rousseau $D$, Vesselle $B$. Neuf saisons de surveillance medicale de competitions de judo: une analyse nationale de la traumatologie du judo en competition. J Traumatologie Sport 2004;21:100-9.

24. Pellman EJ, Powell JW, Viano DC, et al. Concussion in professional football: epidemiological features of game injuries and review of the literature--part 3. Neurosurgery 2004;54:81-96.

25. Echlin PS, Tator CH, Cusimano MD, et al. A prospective study of physician-observed concussions during junior ice hockey: implications for incidence rates. Neurosurg Focus 2010;29:E4.

26. Kemp SP, Hudson Z, Brooks JH, et al. The epidemiology of head injuries in English professional rugby union. Clin J Sport Med 2008:18:227-34.

27. Curran-Sills G. Safety in mixed martial arts: a 7-year review of cancelled mma bouts in calgary, alberta, during the pre-bout medical examination period. Sports Med Open 2018;4:6. 